\title{
MEMORIAL
}

\section{HARRELL L. STRIMPLE}

1912-1983

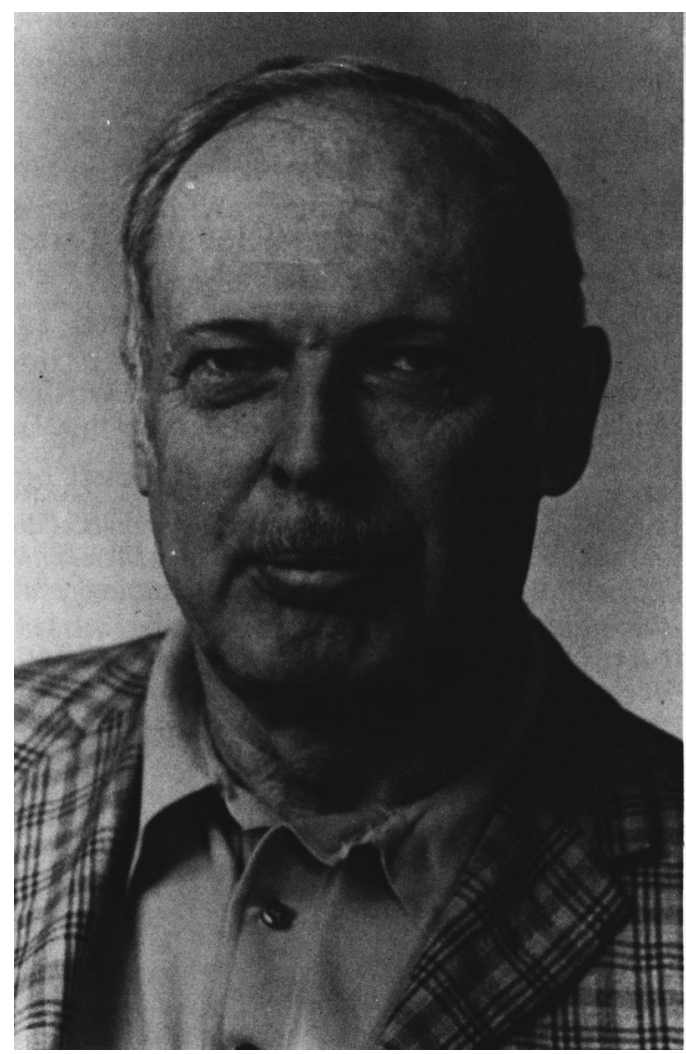

Harrell Strimple was born January 7, 1912, in Yates Center, Kansas. It is difficult to determine when Harrell's love of crinoids developed, but in 1938 it had reached the point that he felt confident enough to publish some of his early discoveries in a personally financed private publication entitled "A Group of Crinoids from the Pennsylvanian of Northeastern Oklahoma." This pamphlet proved to be not only the threshold of an active personal research program that was to last 45 years, but also a pioneer investigation of the great diversity of Pennsylvanian crinoids, a diversity at that time unrealized. In his final oral presentation, at the 9th International Congress of Carboniferous Stratigraphy and Geology in 1979, Harrell summarized the great advances in the knowledge of Pennsylvanian crinoids (Strimple, 1979).
During his "publishing lifetime," Harrell's name appeared on 307 papers and abstracts, and work begun in collaboration with him will be appearing for several years to come. His often repeated philosophy of publication was, "I want to get it recorded." He was acutely aware of the need to publish his new discoveries, and his papers ran the gamut from extensive monographic faunal studies (e.g., Strimple and Moore, 1971) to morphologic details hitherto unknown (e.g., Strimple, 1977). The mood of his papers ranged from the serious (e.g., Strimple and Watkins, 1969) to the fun (e.g., Strimple, 1975) intended to win more devotees to his love of fossil echinoderms.

Harrell was justifiably proud of the impressive list of publication titles he had amassed singly and through collaboration. On rare occasions he would scan the list of years and titles, pointing to a year when he had published 10 or 15 papers, remarking, "Boy, was I hot, then," or "I was really on a roll." He would then glance ruefully at a year with only 3 or 5 titles noting, "I was divorced that year," or "that was when my former wife talked me into getting a TV set." $\mathrm{He}$ acknowledged a lack of personal resistance to the distraction of television and blamed two "bad" years on the presence of a set in the household.

It was during the time that Harrell was serving as an elder in the Pentecostal Church that he met Christina Cleburn, who is from Illinois, has a great interest in crinoids, and was to become his esteemed colleague and wife for the rest of his life. One Sunday during a weekend collecting in Illinois, Harrell had been invited to go to one of Christina's favorite collecting localities. His conservative religious beliefs at the time nearly prevented him from going, but the lure of crinoids was strong. While on the outcrop, they noticed a thunderstorm approaching. Harrell commented that he knew they should never have agreed to go into the field on Sunday and that their punishment would be a thorough drenching, or worse. "Although we might get 
wet," Christina countered, "my farm needs the rain."

Harrell's tendency to "latch on to" prized specimens for research is well-known and even extended to his bride-to-be at the time, Christina. He "borrowed" many of the specimens that she had collected from the now famous locality in the LaSalle Limestone (Strimple and Moore, 1971). She had spent countless hours preparing the specimens and now he had them! Not long after they were married, Harrell and Christina were in central Illinois at a rock and mineral show when a friend of Christina's remarked, "I suppose he married you so he could get your crinoids." Christina promptly replied, "No, I married him to get them back."

Deciding upon new names for the myriad of new taxa he described was a common chore. It was also a tangible way of acknowledging the help of many of the collectors and gifted amateurs who had provided him with material. One of the most beautiful crinoids from the LaSalle Limestone was named for Christina, Brabeocrinus christinae. With so many new generic (288) and specific (702) names, Harrell was sometimes kidded about unusual or non-euphonic combinations. R. C. Moore had criticized Harrell for naming the new genus and species Moundocrinus osagensis (named for the locality called "The Mound" in Osage County, Oklahoma). Moore considered it a bad name and inappropriate because it was not classical. Harrell countered that Moore had no room to talk about unusual names, after he had erected the genus Grenprisia based on a rearrangement of "Springer."

The 1980 Short Course of The Paleontological Society dealt with echinoderms. The organizers and participants dedicated the Short Course Notes to Harrell (Broadhead and Waters, 1980, p. ii), “. . . one of the most colorful and prodigious echinoderm workers of this century ...." Although unable to attend, Harrell sent an appropriate greeting, "Your boss may fire you, your dog may bite you, your wife may leave you (and probably will), but the joy and fascination of crinoids will not let you down." Later, he reflected upon the wording of the dedication (letter to TWB, 1980). "The word, 'colorful' sticks in my mind. Very few will really understand what all is under that blanket but it is a perfect word. It never ceases to amaze me, when I look back, how I even survived. I went hungry one day in the big depression, survived for two years in the ETO in the heart of World War II, a preacher in the most fundamental religious organization of all, a manager-barker in an amusement park, produced two champion show dogs, and some more drastic diversities. What a paradox!" None of these activities, however, was allowed to interfere with his prime goal-the study of crinoids.

In the early days, as an oil company accountant in Bartlesville, Harrell would drive to Iowa on weekends to collect at Gilmore City and LeGrand. On the return trip, he would stop in Lawrence, Kansas, to see Moore and Lowell Laudon and to gloat over his collections from the weekend. One Sunday, Moore and Laudon cautiously questioned Harrell about the exact site he had collected at Gilmore City. They had uncovered a large crinoid colony and were relieved to know that he had not found it. Knowing that Harrell was due to work the next morning in Bartlesville, they told him of their find. Harrell promptly thanked them and, upon leaving, called in sick at work, raced back to Gilmore City, and collected the colony.

Harrell's relationship with Moore was not always so competitive. They coauthored numerous articles, many of which were published as Papers and Articles of University of Kansas Paleontological Contributions, a series over which Moore exerted considerable influence. On one occasion they had prepared a manuscript for the Papers series and also had submitted an abstract for presentation at a meeting. Harrell recounted that as he was beginning the talk he remarked that the paper would be published "any day now." Looking to the rear of the meeting room he saw Moore, handing out reprints to the audience.

As his retirement neared, maintaining his research activity at a constant high level became more difficult. He philosophized (letter to TWB, 1981), "I should be working, but find that I cannot keep control of my mind, which factor is sure playing havoc with my production record. But why in the world should I care at this stage in life?? I have been looking back over the past and attempting to project into the future, which I guess is a normal reaction in one's older time in life. 


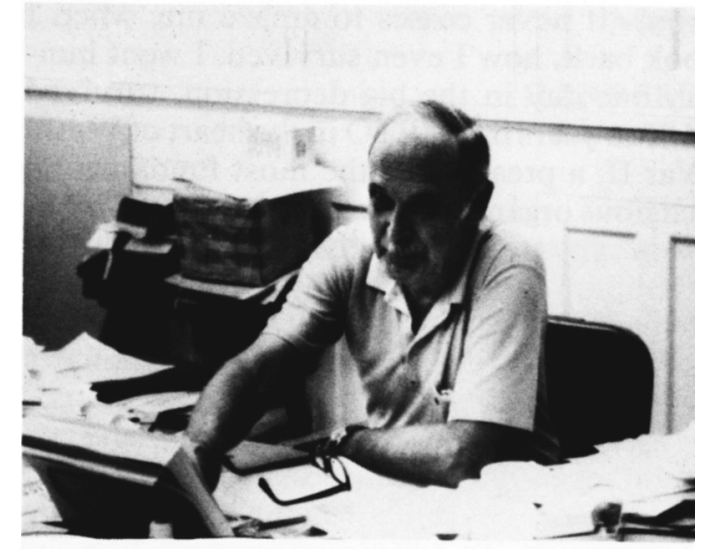

Just recently I found that I am older than Ubaghs which makes me the 'elder' crinoid authority today. With Caster still alive I cannot claim the same status for echinoderms in general. I no longer have a goal of being 'the greatest', but would still like to leave a mark so high on the tree that it will be hard to top. I did not get this far without a lot of cooperation and help, and now I need it more than ever in order to finish up some of the projects that I have pulled together. There was a time when I would have said 'to hell with it' and dug in myself, but I just cannot do it anymore."

"Would you believe the balance of the Algerian Carboniferous crinoids arrived on my birthday! Fortunately they have not declared a National Holiday for it (as yet), else I would have been forced to wait a day for delivery! In any event it is very exciting. A swarm of camerates persist into the upper Visean, into Westphalian B, and may be more than I bargained for."

Harrell was in the Army in England during World War II, and, as you can imagine, he was not a model soldier. He was sitting on his Army bunk looking at a slab of crinoids. He had on an optivisor and was totally engrossed in his microscopic world. His captain entered the room and someone yelled "attention," but of course Harrell didn't hear it or it didn't register. The captain walked up to the bed and stared at his disobedient charge, and Harrell, with the crinoid slab still on his lap and his optivisor still lowered, calmly looked up at him. Finally the captain just walked away without saying a word. Not only did Harrell avail himself of the splendid col- lecting in the British and Belgian Carboniferous, but also coauthored two papers with James Wright while stationed in Britain.

As curator and research associate at the University of Iowa, Harrell was constantly visiting and being visited by a veritable army of gifted amateurs and collectors, important sources for much of his published material. His outgoing manner, generosity, and wit endeared him to them. He was one of them, an extremely gifted amateur turned professional much in the same mold as Frank Springer, Charles Schuchert, and a host of nineteenth century giants of paleontology. Visits to his office were always an experience. A friendly handshake and the question, "What have you come up with this time?" was the usual greeting. A box would be taken out, carefully wrapped specimens would be handed to Harrell, and the anxious visitor would ask, "Which one is it?" Knowing full well to which genus each belonged, Harrell would look closely at the specimens, hand them back, smile, and say, "They're probably crinoids," then continue, "you're planning to leave them at the repository, aren't you?" After a couple of days, the visitor would receive a letter from Harrell in which he identified the specimens and gave a detailed description of everything in the box. On occasion, rather than postpone identification, Harrell would say, "there's the microscope," then point out the minute differences between species.

A visit to the Strimple home was yet another experience for amateur and professional alike. Chairs, cabinets, and tables piled high, sometimes too high, with manuscripts, notes, reprints, and journals set a precarious mood for the evening. Next to the sofa, the end table held a Wild microscope and a clutter of small boxes of specimens. After viewing the new specimens, adjournment would be to the dining table for iced tea. Conversation would become more intensely echinodermal until about 8 P.M. when Harrell would ask, "Care for a drink?" and out would come the bottle of Jim Beam. It was usually up to the visitor to "break up" the evening; it would continue otherwise into the small hours with the discussion of echinoderms unabated.

The few years of his retirement saw no real change in Harrell, and his retirement came with little ado. His office library and current study specimens were moved downstairs to 
smaller quarters, but he continued to work on a myriad of projects. He became especially active with the Mid America Paleontology Society, a relatively new organization for both amateur and professional paleontologists in the upper midwest. This seems especially characteristic because Harrell had long been that rare hybrid of amateur turned professional and had always tried to bring amateur collectors together with professionals - all to the benefit of science.

Harrell long had believed that gifted amateur paleontologists had received too little recognition for their cooperation in bringing important specimens to the attention of the paleontological community. In 1982, he made a generous gift to The Paleontological Society, the income from which was to fund an award to recognize the outstanding scientific accomplishments of an amateur paleontologist. Although Harrell had intended that the award be named for $\mathrm{R}$. C. Moore, a request was made that he permit the award to be named the Harrell L. Strimple Award. He acquiesced to this suggestion and continued to contribute to the award fund until his death.

Harrell L. Strimple died on August 21, 1983. He was a Patron of The Paleontological Society, a Fellow of the Iowa Academy of Sciences, and a member of the Paleontological Research Institution, the Geological Society of America, and the Mid America Paleontology Society. His body was cremated and his ashes scattered over one of his favorite collecting sites-The Mound, Osage County, Oklahoma.

\section{ACKNOWLEDGMENTS}

The authors thank the following echinoderm workers and friends of Harrell for their financial and anecdotal contributions to this memorial: William I. Ausich, Bruce M. Bell, Arthur L. Bowsher, Thomas W. Broadhead, James C. Brower, Kenneth E. Caster, Don Chestnut, Jr., Glenn C. Crossman, Frank R. Ettensohn, Arthur J. Gerk, Julia Golden, Alan S. Horowitz, Porter M. Kier, Dennis Kolata, N. Gary Lane, Calvin O. Levorson, Ronald D. Lewis, D. Bradford Macurda, Jr., James F. Miller, Roger K. Pabian, Ronald L. Parsley, George D. Sevastopulo, James Sprinkle, Gary D. Webster, and Brian J. Witzke.

THOMAS W. BROADHEAD University of Tennessee Terrence J. Frest Iowa City, Iowa

\section{REFERENCES}

BroadheAd, T. W. AND J. A. WATERS (eds.). 1980. Echinoderms, notes for a short course. University of Tennessee Studies in Geology, 3:i-iv, 1235.

Strimple, H. L. 1975. The fascination of crinoids. Earth Science, 28:117-121.

- 1977. A youthful specimen of Stenopecrinus ornatus (Crinoidea - Inadunata). Journal of Paleontology, 51:423-424.

- 1979. Pennsylvanian crinoids: state of the art after forty years. Ninth International Congress of Carboniferous Stratigraphy and Geology, Abstracts of Papers, p. 210.

- AND R. C. MOORE. 1971. Crinoids of the LaSalle Limestone (Pennsylvanian) of Illinois. University of Kansas Paleontological Contributions, Article 55 (Echinodermata 11):1-48.

- AND W. T. WatkIns. 1969. Carboniferous crinoids of Texas with stratigraphic implications. Palaeontographica Americana, 6:141-275. 